\title{
Physiological characterization of rice under salinity stress during vegetative and reproductive stages
}

\author{
Farshid Aref $^{2 *}$ and Hassan Ebrahimi Rad ${ }^{1}$ \\ ${ }^{1}$ Department of Soil Science, Firouzabad Branch, Islamic Azad University, Iran \\ $2^{*}$ Department of Irrigation and Drainage, Firouzabad Branch, Islamic Azad University, Iran \\ *farshidaref@yahoo.com; farshidaref@iauf.ac.ir
}

\begin{abstract}
Salinity is one of the major environmental factors limiting crop productivity. For this reason, a greenhouse experiment was conducted in Rasht, North of Iran during 2010 growing season to evaluate the salinity levels of irrigation water at different growth stages on the some physiological characterization of rice. Treatments were arranged in a randomized complete block design with two factors and three replications. Factor one included four levels of saline water $\left(2,4,6\right.$, and $\left.8 \mathrm{dS} \mathrm{m}^{-1}\right)$; factor two consisted of four growth stages (tillering, panicle initiation, panicle emergence and ripening). The results of this work showed that effect of different salinity levels on the all yield components except percentage of filled grains per panicle was not significant. Increase in salinity levels decreased this component. Effect of different growth stages on total number of empty grains per panicles, percentage of filled grains per panicle, number of unfilled panicles and percentage of ratio of number of unfilled panicles to tillers was significant but effect of different saline water on length of unfilled panicle and number of spikelets per unfilled panicle was insignificant. Resistance of final growth stages, i.e. panicle emergence and ripening stages against salinity was more than primary growth stages, i.e. tillering and panicle initiation. Therefore, in irrigation with saline water the final growth stages were important and irrigation with saline water should be applied at final growth stages.
\end{abstract}

Keywords: Saline water, Salt tolerance, Growth stages, Yield components, Panicle.

\section{Introduction}

The most important cereal crop in the world is rice, yielding one-third of the total carbohydrate source. Three billion people consider rice as their stable food, accounting for $50-80 \%$ of their daily calorie intake. Rice is a salt-sensitive monocot (Darwish et al., 2009;Maas \& Hoffman, 1997; Shereen et al., 2005). Salinity is a limiting environmental factor for plant production, and is becoming more prevalent as the intensity of agriculture increases. Around the world, 100 million ha, or $5 \%$ of arable land, is adversely affected by high salt concentrations, which reduce crop growth and yield (Ghassemi et al., 1995; Gunes et al., 2007).

Salt and drought stresses have toxic effects on plants and lead to metabolic changes, like loss of chloroplast activity, decreased photosynthetic rate and increased photorespiration rate which then lead to an increased reactive oxygen species production (Winicov, 1993; Hoshida et al., 2000; Teixeira \& Pereira 2007). Soil salinity is considered as one of the major factors that reduce plant growth in many regions in the world. Soils in the arid and semiarid regions have excessive concentrations of soluble salts, which adversely affect plant growth. Two important limitations for crop production in arid and semi-arid regions are water shortage and poor quality. Different methods of water (Sepaskhah \& Yousofi-Falakdehi 2010). In salt-affected soil, there are many salt contaminants, especially $\mathrm{NaCl}$ which readily dissolves in water to yield the toxic ions, sodium ion $\left(\mathrm{Na}^{+}\right)$and chloride ion $\left(\mathrm{Cl}^{-}\right)$. Also, the water available in the salt-contaminated soil is restricted, inducing osmotic stress (Castillo et al., 2007; Pagter et management are used to cope with water shortage

al., 2009; Siringam et al., 2011). Salinity and sodicity can reduce plant growth and alter ionic relations by ionic and osmotic effects and oxidative stress (Borsani et al., 2001; Eraslan et al., 2007; Tarakcioglu \& Inal 2002). Salinity inhibits plant growth in three principle ways: by ion toxicity (mainly of $\mathrm{Na}^{+}$and $\mathrm{Cl}^{-}$), osmotic stress, and nutritional disruption (Caines \& Shennan, 1999). Accumulation of toxic levels of $\mathrm{NaCl}$ in the cytoplasm must therefore be avoided. Plant adaptations to salinity include sequestration of salt ions in vacuoles and accumulation of 'compatible compounds', such as sugars, proline and glycinebetaine in the cytoplasm to balance the osmotic pressure (Hopkins, 1999; Jampeetong \& Brix 2009). Dhanapackiam \& Muhammad llyas (2010b) showed that $\mathrm{NaCl}$ had a greater effect on osmotic pressure.

Salt stress is one of the most important abiotic stresses that adversely affect natural productivity and causes significant crop loss worldwide. Almost every aspect of the plant's physiology and biochemistry is affected (Darwish et al., 2009). The deleterious effects of salinity on plant growth are associated with (i) low osmotic potential of soil solution (water stress), (ii) nutritional imbalance, (iii) specific ion effect (salt stress), or (iv) a combination of these factors (Ashraf \& Harris 2004; Marschner, 1995). All of these cause adverse pleiotropic effects on plant growth and development at physiological and biochemical levels and at the molecular level (Munns, 2002; Tester \& Davenport 2003; Winicov, 1998). Many enzymatic activities of plants are adversely affected by high $\mathrm{Na}^{+}$concentration (Maathuis \& Amtmann 1999). Salt tolerance is related to exclusion of $\mathrm{Na}^{+}$ion and distribution of almost uniform concentration of this ion in all leaves (Ashraf \& O'Leary 1995; Haq et al., 2009).

Research article

CIndian Society for Education and Environment (iSee)

"Salinity stress"

http://www.indjst.org
F.Aref \& H.E.Rad Indian J.Sci.Technol. 
The phytotoxicity of $\mathrm{NaCl}$ is likely due to its ability to generate reactive oxygen species (ROS) represented predominantly by superoxide anion $\left(\mathrm{O}_{2}{ }^{-}\right)$, hydrogen peroxide $\left(\mathrm{H}_{2} \mathrm{O}_{2}\right)$, and hydroxyl radicals $(\mathrm{OH})$ (Huang et al., 2005; Tanou et al., 2009; Tuteja, 2007; Verma \& Mishra 2005).

In salt-susceptible (glycophytes) plant species, biochemical, physiological and morphological characteristics are negatively affected, leading to abnormal growth and development, and eventual plant death (Hasegawa et al., 2000; Nishimura et al., 2011; Parida \& Das 2005). Most cultivated plants are glycophytes with limited compartmentation of $\mathrm{NaCl}$. Glycophytes are not as effective as halophytes in ionic partitioning at the cellular level, but more effective at the plant and tissue level (Lauchli \& Epstein 1990). The energy requirement for salt exclusion in glycophytes explains in part the stimulation of root respiration by soil salinity (salt respiration) and the loss of net synthesis of organic C (Eynard et al., 2005; Lambers et al., 1998). Concerning halophytic plants that are tolerant of sodium toxicity, osmotic stress might be the main reason of growth inhibition (Turkan \& Demiral 2009). Upon prolonged exposure of a plant to $\mathrm{NaCl}, \mathrm{Na}^{+}$is translocated from the roots to the transpiring leaves, where it can reach toxic levels. Many of the mechanisms that enable plants to tolerate high soil salinity are related to the maintenance of low $\mathrm{Na}^{+}$in shoots (Quintero et al., 2008; Tester \& Davenport 2003). There are several defense mechanisms against salt in salt-tolerant, or halophyte, species, such as osmoregulation (glycinebetaine and proline), antioxidants (enzymatic and nonenzymatic agents), ion homeostasis, and hormonal systems (Cha-um \& Kirdmanee 2010; Hasegawa et al., 2000; Singh et al., 2008; Vaidynathan et al., 2003). When salt is first encountered by a plant, there are two phases to its response. The first phase is a response to the changed water relations brought about by the lowering of the external water potential by the salt. These initial effects of salinity (phase 1 , due to a change in water potential) are likely to be the same for cultivars of differing salt tolerance. Only as ions are accumulated over time (phase 2) do true difference in salt tolerance appear (Flowers \& Flowers 2005; Munns, 1993). Sensitive cultivars accumulate ions more quickly than tolerant cultivars and this ion accumulation leads to leaf death and, progressively, death of the plant (Flowers \& Flowers 2005; Munns, 2002). The reduced water potential at saline habitats creates in the plant a two-edged problem: a corresponding water and ion stress. The uptake and accumulation of $\mathrm{Na}^{+}$and $\mathrm{Cl}^{-}$into the different plant organs is highly controlled (Hasegawa et al., 2000; Marschner, 1995), salt-resistant species often possess special features to remove $\mathrm{NaCl}$ from the cytoplasm, e.g. by compartmentation in the vacuole (Koyro, 2006; Muhling \& Lauchli 2002).
Vol. 5 No. 4 (Apr 2012)

ISSN: 0974- 6846
Crop yield response to soil salinity depends on soil water regime, which is modified by irrigation amounts, frequency and salinity of irrigation water (Eynard et al., 2005). The use of saline water for irrigation requires study of long-term changes in soil salinity because under conditions of drought, soil may be in the state of salt accumulation, with soil salinity exceeding the tolerant limit for crops (Yang-Ren et al., 2007). The high levels of salts in irrigation water can restrict or even scupper the rice cultivation, also by the presence of some elements in toxic concentrations (Fraga et al., 2010; Silva, 2004). Rice is considered as moderately salt sensitive crop fort the newly reclaimed saline areas. Therefore, developing salinity tolerance rice varieties is a very important approach not only for increasing yields, but also for conquering saline soils (El-Mouhamady et al., 2010). Dhanapackiam \& Muhammad llyas (2010a) studied effect of salinity on chlorophyll and carbohydrate contents of sesbania grandiflora seedlings and showed significant positive influence of higher salinity concentrations on the parameters. Zeng \& Shannon (2000) found that seedling growth was adversely affected at salinity levels as low as $1.9 \mathrm{dS} \mathrm{m}^{-1}$, but this effect did not translate into a reduction in grain yield. Asch \& Wopereis (2001) studied the effect of field-grown irrigated rice cultivars to varying levels of floodwater salinity and concluded that use of salinity tolerant cultivars, drainage if floodwater EC $>2 \mathrm{dS}$ $\mathrm{m}^{-1}$ at critical growth stages, and early sowing in the WS to avoid periods of low air humidity during the crop cycle, are ways to increase rice productivity.

Therefore, the objective of this work aims to investigate the effect of different salinity levels on some physiological characterization of rice.

\section{Materials and methods}

To determine salt sensitivity for rice (Oryza sativa L.) at various growth stages, a factorial experiment arranged as randomized complete block design with three replications was performed at the Rice Research Institute in Rasht, North of Iran during May to July 2010. The site is situated at latitude $37^{\circ} 12^{\prime} \mathrm{N}$ and longitude $49^{\circ} 38^{\prime} \mathrm{E}$ and $32 \mathrm{~m}$ altitude. Hashemi, as a widely cultivated variety in Guilan province, was used. Two factors tested in this experiment. The first factor was different levels of salinity in irrigation water (including four levels of salinity: 2, 4, 6 and $8 \mathrm{dSm}^{-1}$ ) and the second factor was the time of impelling salinity in different levels of rice growth stages (including tillering, panicle initiation, panicle emergence and ripening stages).

The experiment conducted in greenhouse condition (pot under shelter) in order to prevent from effecting unwanted factors and to have a better control on condition. Dates of rice cultivation stages in the project were: date of transplanting - May 23, date of impelling salinity in tillering stage - June 6 , date of impelling salinity in panicle initiation - June 17, date of impelling salinity in panicle emergence - June 27 , date of impelling salinity in ripening stage - July 23. 3 transplants which were grown
Research article

Clndian Society for Education and Environment (iSee)
"Salinity stress" http://www.indjst.org
F.Aref \& H.E.Rad Indian J.Sci.Technol. 
Vol. 5 No. 4 (Apr 2012)

ISSN: 0974- 6846

Table 1. Analysis of variance for yield components as affected by salinity levels at different growth stages

\begin{tabular}{|c|c|c|c|c|c|c|c|}
\hline $\begin{array}{l}\text { Sources of } \\
\text { variation }\end{array}$ & & $\begin{array}{c}\text { Length of } \\
\text { unfilled panicle }\end{array}$ & $\begin{array}{l}\text { Number of } \\
\text { spikelets per } \\
\text { unfilled } \\
\text { panicle }\end{array}$ & $\begin{array}{l}\text { Total number of } \\
\text { empty grains per } \\
\text { panicles }\end{array}$ & $\begin{array}{l}\text { Percentage } \\
\text { of filled } \\
\text { grains per } \\
\text { panicle }\end{array}$ & $\begin{array}{c}\text { Number of } \\
\text { unfilled } \\
\text { panicles }\end{array}$ & $\begin{array}{c}\text { Percentage of } \\
\text { ratio of number of } \\
\text { unfilled panicles } \\
\text { to tillers }\end{array}$ \\
\hline & $\mathrm{df}$ & Mean squares & & & & & \\
\hline Replication (R) & 2 & $11.79^{\text {ns }}$ & $5.61^{\mathrm{ns}}$ & $19659.77^{\text {ns }}$ & $238.19^{\mathrm{ns}}$ & $25.33^{n s}$ & $313.01^{\text {ns }}$ \\
\hline $\begin{array}{l}\text { Growth stages } \\
\text { (GS) }\end{array}$ & 3 & $17.79^{\mathrm{ns}}$ & $2.07^{\mathrm{ns}}$ & $148278.58^{* *}$ & $1669.81^{\star *}$ & $45.47^{*}$ & $618.64^{*}$ \\
\hline Salinity levels (SL) & 3 & $15.19^{\mathrm{ns}}$ & $3.41^{\mathrm{ns}}$ & $4879.19^{n s}$ & $557.72^{\star \pi}$ & $2.47^{\mathrm{ns}}$ & $110.95^{\mathrm{ns}}$ \\
\hline $\mathrm{GS} \times \mathrm{SL}$ & 9 & $11.40^{\mathrm{ns}}$ & $7.09^{n s}$ & $21106.81^{\mathrm{ns}}$ & 375.20 & $17.27^{\mathrm{ns}}$ & $270.31^{n s}$ \\
\hline Error & 3 & $6.83^{\mathrm{ns}}$ & $5.41^{\mathrm{ns}}$ & $27329.19^{\mathrm{ns}}$ & $122.19^{\mathrm{ns}}$ & $12.33^{\mathrm{ns}}$ & $168.15^{\mathrm{ns}}$ \\
\hline CV\% & & 16.28 & 57.79 & 57.24 & 15.78 & 86.89 & 79.67 \\
\hline
\end{tabular}

Table 2. Mean comparison of salinity levels at different growth stages affected on yield components of rice The same letters are not significantly different in each column $(p<0.05)$ by Duncan's test

\begin{tabular}{|l|c|c|c|c|c|c|}
\hline & $\begin{array}{c}\text { Length of } \\
\text { unfilled } \\
\text { panicle }\end{array}$ & $\begin{array}{c}\text { Number of } \\
\text { spikelets per } \\
\text { unfilled panicle }\end{array}$ & $\begin{array}{c}\text { Total number of } \\
\text { empty grains } \\
\text { per panicles }\end{array}$ & $\begin{array}{c}\text { Percentage of } \\
\text { filled grains } \\
\text { per panicle }\end{array}$ & $\begin{array}{c}\text { Number of } \\
\text { unfilled } \\
\text { panicles }\end{array}$ & $\begin{array}{c}\text { Percentage of } \\
\text { ratio of number } \\
\text { of unfilled } \\
\text { panicles to tillers }\end{array}$ \\
\hline $\begin{array}{c}\text { Salinity levels } \\
(\mathrm{dS} / \mathrm{m})\end{array}$ & & & & & & \\
\hline 2 & $15.94 \mathrm{a}$ & $4.72 \mathrm{a}$ & $313.58 \mathrm{a}$ & $74.22 \mathrm{ab}$ & $3.50 \mathrm{a}$ & $12.35 \mathrm{a}$ \\
\hline 4 & $16.23 \mathrm{a}$ & $3.74 \mathrm{a}$ & $270.75 \mathrm{a}$ & $77.15 \mathrm{a}$ & $4.42 \mathrm{a}$ & $16.33 \mathrm{a}$ \\
\hline 6 & $17.40 \mathrm{a}$ & $4.14 \mathrm{a}$ & $296.75 \mathrm{a}$ & $66.47 \mathrm{ab}$ & $3.83 \mathrm{a}$ & $16.70 \mathrm{a}$ \\
\hline 8 & $14.66 \mathrm{a}$ & $3.49 \mathrm{a}$ & $274.08 \mathrm{a}$ & $62.36 \mathrm{~b}$ & $4.42 \mathrm{a}$ & $19.95 \mathrm{a}$ \\
\hline Growth stages & & & & & & $16.06 \mathrm{ab}$ \\
\hline Tillering & $14.77 \mathrm{a}$ & $3.60 \mathrm{a}$ & $201.33 \mathrm{~b}$ & $69.57 \mathrm{a}$ & $3.50 \mathrm{ab}$ & $26.53 \mathrm{a}$ \\
\hline Panicle initiation & $15.27 \mathrm{a}$ & $4.59 \mathrm{a}$ & $443.58 \mathrm{a}$ & $53.82 \mathrm{~b}$ & $6.92 \mathrm{a}$ & $10.58 \mathrm{~b}$ \\
\hline $\begin{array}{l}\text { Panicle } \\
\text { emergence }\end{array}$ & $17.19 \mathrm{a}$ & $3.89 \mathrm{a}$ & $215.17 \mathrm{~b}$ & $81.09 \mathrm{a}$ & $2.67 \mathrm{~b}$ & $12.16 \mathrm{ab}$ \\
\hline Ripening & $17.01 \mathrm{a}$ & $4.01 \mathrm{a}$ & $295.08 \mathrm{ab}$ & $75.72 \mathrm{a}$ & $3.08 \mathrm{ab}$ & 5.40 \\
\hline Control & 20.13 & 4.75 & 229.00 & 80.87 & 1.00 & 2 \\
\hline
\end{tabular}

in ordinary condition cultivated in pots with diameter and deepness of $25 \mathrm{~cm}$ filled with agricultural soil. 7 days later, plants were irrigated with ordinary water. Flooded irrigation with $5 \mathrm{~cm}$ height was the first stage to perform treatments. After each growth stage, leaching with ordinary water was done and irrigation with ordinary water finished. All agricultural stages conducted in a normal way and in the same way based on what was usual in the region.

Required salinities in irrigation water obtained by pure $\mathrm{NaCl}$ and $\mathrm{CaSO}_{4}$ with a ratio of 2:1 and pots irrigated with them. Basic water requires to provide different levels of salinity, therefore $425 \mathrm{gr} \mathrm{NaCl}$ and 215 gr $\mathrm{CaSO}_{4}$ was added to 100 liters ordinary water $(\mathrm{EC} \leq 1$ $\left.\mathrm{dS} \mathrm{m}^{-1}\right) .2 \mathrm{dS} \mathrm{m}^{-1}$ salinity obtained through adding 10 liters basic water in 90 liters ordinary water. $4 \mathrm{dS} \mathrm{m}^{-1}$ salinity obtained by adding 35 liters basic water in 65 liters ordinary water. For $6 \mathrm{dS} \mathrm{m}^{-1}$ salinity 60 liters basic water and 40 liters ordinary water were mixed. Also $8 \mathrm{dS}$ $\mathrm{m}^{-1}$ salinity concluded from 86 liters basic water and 22 liters ordinary water.

All treatments fertilized for 2 times: first on the May 26 , and second time on the June $24.6 \mathrm{~kg}$ urea (with $46 \%$ $\mathrm{N}$ ), $8 \mathrm{~kg}$ potassium sulfate (with $50 \% \mathrm{~K}_{2} \mathrm{O}$ ) and $6 \mathrm{~kg}$ triple Research article (C)Indian Society for Education and Environment (iSee)

"Salinity stress" http://www.indjst.org super phosphate (with $46 \% \mathrm{P}_{2} \mathrm{O}_{5}$ ) were mixed and added to the treatments adequately. Leaching conducted to prevent accumulation of salt on the July 21. After ripeness, some physiological characterization such as length of unfilled panicle, number of spikelets per unfilled panicle, total number of empty grains per panicles, percentage of filled grains per panicle, number of unfilled panicles and percentage of ratio of number of unfilled panicles to tillers were measured.

Analysis of variance (ANOVA) was performed on all experimental data and means were compared using the Duncan's multiple range test with SAS software (SAS, 2001). All data were checked for normality before being analysed. The significance level was $P<0.05$.

\section{Results and discussion}

Length of unfilled panicle

Effect of different growth stages and also different levels of salinity on length of unfilled panicle (Table 1) was not significant $(P<0.05)$. High effectiveness of salinity on length of unfilled panicles of rice has been reported by many researchers (Khan et al., 1997).

Conclusions of mean comparison of length of unfilled panicle (Table 2) showed that control treatment with fresh water irrigation $\left(1 \mathrm{dSm}^{-1}\right)$ had the longest length of 
unfilled panicle $(20.13 \mathrm{~cm})$. Increasing salinity resulted in shorter length of unfilled panicle in compare with control treatment but there were not any significant differences between different levels of salinity. The shortest length of unfilled panicle $(14.66 \mathrm{~cm})$ was at $8 \mathrm{dSm}^{-1}$; this treatment showed $27 \%$ decrease in compare with control treatment.

Effect of different growth stages of rice on length of unfilled panicle was different. The most length of unfilled panicle (17.19) observed in panicle emergence and the least amount (14.77) observed in tillering stage. Of course there were not any significant differences between different growth stages. Momayezi et al. (2009) stated that salt composition can affect rice growth at germination and early seedling stages.

In a survey of interaction effect of different levels of salinity and different growth stages it was found that the most length of unfilled panicle $(21.72 \mathrm{~cm})$ was in ripening at $6 \mathrm{dSm}^{-1}$ salinity and its least amount (13.17) was in tillering stage at $2 \mathrm{dSm}^{-1}$ salinity.

\section{Number of spikelets per unfilled panicle}

Conclusions of variance analysis (Table 1) showed that effect of different growth stages and also different levels of salinity on number of spikelets per unfilled panicle was not significant $(P<0.05)$. The loss of potential spikelets are due to the degeneration of primary and secondary branches and flower primordial (Zeng \& Shannon 2000). High effectiveness of salinity on number of spikelets has been reported by many researchers (Zeng et al., 2003). Number of spikelets affects by salinity (Zeng et al., 2003).

With regard to the conclusions of mean comparison of number of spikelets per unfilled panicle (Table 2), the most number of spikelets per unfilled panicle (4.75) observed in control treatment. Increasing salinity decreased number of spikelets per unfilled panicle, so that at $8 \mathrm{dSm}^{-1}$ salinity spikelets per unfilled panicle reduced up to $26 \%$ in compare with control treatment. Also the least number of spikelets per unfilled panicle was 3.49 at $8 \mathrm{dSm}^{-1}$. Although different levels of salinity decreased spikelets per unfilled panicle, but there were not any significant differences between these levels and all levels placed in the same statistical class.

In different growth stages of rice, number of spikelets per unfilled panicle was different. The most number of spikelets per unfilled panicle (4.59) was in panicle initiation and the least average number (3.60) was in tillering stage. Increasing unfilled panicle decreases rice yield; with regard to this matter that there were not any significant differences between different levels of salinity and growth stages, therefore, effect of salinity on yield reduction is less affected by number of spikelets per unfilled panicle.

Survey on interaction effect of different salinity and growth stages showed that the most number of spikelets per unfilled panicle (8.33) observed in panicle initiation at $2 \mathrm{dSm}^{-1}$ and the least average number (2.83) observed in panicle initiation at $4 \mathrm{dSm}^{-1}$ salinity.

Research article

(C)Indian Society for Education and Environment (iSee)

\section{Total number of empty grains per panicles}

With regard to the conclusions of variance analysis (Table 1), different growth stage of rice had different sensitivity to salinity. Effect of different growth stages on total number of empty grains per panicles was significant $(P<0.01)$ but effect of different levels of salinity on it was not significant $(P<0.05)$. High effectiveness of salinity on number of empty grains has been reported by many researchers. Increased number of incompletely filled grains might be a result of assimilate shortage during grain filling, brought about by early leaf senescence caused in this case by salinity (Fabre et al., 2005; Murchie et al., 2002; Sheehy et al., 2001; Zaibunnisa et al., 2002; Zeng \& Shannon 2000). Frequently, many spikelets on the lower primary branches do not produce a mature grain, and this loss of potential grains may adversely affect the grain number and yield. This failure in spikelet development has been attributed to a limitation in carbohydrate supply to the developing panicle (Abdullah et al., 2001).

Conclusions of mean comparison of total number of empty grains per panicles (Table 2) showed that control treatment $\left(1 \mathrm{dSm}^{-1}\right)$ had the least total number of empty grains per panicles (229.00). Treatments of 2, 4, 6 and 8 $\mathrm{dSm}^{-1}$ had total number of empty grains per panicles respectively as follow: $313.58,270.75,296.75$, and 274.08 which all placed in the same statistical class. These salinity level increased total number of empty grains per panicles in compare with control treatment (37, 18,29 and $20 \%$ increase, respectively). Increasing empty grain decreases rice yield. Therefore increased salinity resulted in increased total number of empty grains per panicles and finally it decreases yield. Sterility and reduction in seed set were primarily due to reduced translocation of soluble carbohydrates to primary and secondary spikelets, accumulation of more sodium and less potassium in all floral parts and inhibition of the specific activity of starch synthetase in developing rice grains, thus reducing seed set (Abdullah et al., 2001).

Different growth stage showed different reaction to total number of empty grains per panicles. The most total number of empty grains per panicles (443.58) observed in panicle initiation and its least amount (201.33) observed in tillering stage. Panicle initiation is the most sensitive stage to salinity and after that were ripening, panicle emergence and tillering stages. An increased empty grain is an important factor to decrease yield. So in panicle initiation which numbers of empty grain increased, yield increased too. At germination and during maturation rice exhibits its highest tolerance. However, salt stress in all developmental stages of rice can contribute to yield losses (El-Saidi, 1997). Rice has previously been reported to be salt-sensitive at the seedling and reproductive stages, leading to a reduction in crop productivity (Moradi \& Ismail, 2007; Zeng \& Shannon, 2000; Zeng et al., 2001). 
In survey on reciprocal effect of different levels of salinity and growth stages (Fig.1) the most total number of empty grains per panicles (533.67) observed in panicle initiation at $6 \mathrm{dS} \mathrm{m}^{-1}$ and the least amount (131) observed in tillering stage at $4 \mathrm{dSm}^{-1}$.

Percentage of filled grains per panicle

Conclusions of variance analysis showed that different growth stages have different sensitivity to salinity (Table 1). Effect of different growth stages, different levels of salinity and also their interaction effect on percentage of filled grains was significant $(P<0.01)$. Salinity is one of the major environmental factors limiting plant growth and yield (Parida and Das, 2005). High effectiveness of salinity on grains has been reported by many researchers (Beatriz et al., 2001). Beatriz (2001) reported that salinity of soil or water decreases number of grain per panicle and harvest index. Pollen viability, a very important trait that is greatly influenced by the ionic toxicity under salinity, was found to be a governing trait for the ultimate grain yield (Mohammadi Nejada et al., 2010).

Conclusions of mean comparison of percentage of filled grains per panicle (Table 2) showed that control treatment had the most percentage of filled grains per panicle (80.87). Increasing different levels of salinity resulted in decreased percentage of filled grains per panicle, so that treatments of $2,4,6$ and $8 \mathrm{dSm}^{-1}$ decreased percentage of filled grains per panicle $(8,4$, $18,23 \%$, respectively) in compare with control. The least percentage of filled grains per panicle (62.36) observed at $8 \mathrm{dS} \mathrm{m}^{-1}$. In general, crops are less sensitive to salinity in glasshouse conditions than outdoors, where wind, low relative humidity and extreme temperatures may increase evapotranspiration (Eynard et al., 2005).

Percentage of filled grains per panicle in different growth stages was different. The most percentage of filled grains per panicle (81.09) observed in panicle emergence and the least amount (53.82) observed in panicle initiation. The most sensitive stage to salinity was panicle initiation and after that were tillering, ripening and panicle emergence. Crops were most sensitive during vegetative and early reproductive stages, less sensitive during flowering and least sensitive during the seed filling stage (Lauchli \& Grattan 2007). There are other reports where grain yield is much more depressed by salt than the vegetative growth (other than that of very young seedlings) (Cui et al., 1995; Khatun \& Flowers, 1995; Khatun et al., 1995; Shereen et al., 2005). As plants mature, they become progressively more tolerant to salinity, particularly at later stages of development (Lauchli \& Grattan 2007).

Therefore resistance of final growth stages, i.e. panicle emergence and ripening stages against salinity was more than primary growth stages, i.e. tillering and panicle initiation.

With regard to Fig.2, survey on reciprocal effect of different level of salinity and growth stages showed that
Vol. 5 No. 4 (Apr 2012) ISSN: 0974- 6846 the most percentage of filled grains per panicle amounted 86.25 , observed in tillering at $4 \mathrm{dSm}^{-1}$ and the least amount (41.64), observed in panicle initiation at $6 \mathrm{dSm}^{-1}$. Number of unfilled panicles

Effect of different growth stages on number of unfilled panicles was significant (Table 1) but effect of different levels of salinity on it was not significant $(P<0.05)$. High effect of salinity on rice and rice sensitivity to salinity of irrigation water has been reported by many researchers (Asch \& Wopereis 2001; Beatriz et al., 2001). Beatriz (2001) reported that salinity of water or soil decreases number of panicles in rice.

With regard to the conclusions of mean comparison of number of unfilled panicles (Table 2), control treatment $\left(1 \mathrm{dSm}^{-1}\right)$ had the least number of unfilled panicles (1.00). Increased level of salinity resulted in increased unfilled panicles. Of course, there were not any significant differences between different levels of salinity. Whatever number of unfilled panicles is more, amount of yield decreases. Therefore, the salinity decreases yield through increasing unfilled panicles. Khatun and Flowers (1995) studied the effect of $\mathrm{NaCl}$ salinity on sterility and seed set in rice. Salinity increased the number of sterile florets and viability of pollen, becoming more pronounced with increased salinity. Drought during grain filling is also known to cause incomplete filling associated with reduced specific weight of kernels (Tsuda, 1993).

Different growth stages showed different effectiveness on number of unfilled panicles. The most unfilled panicles (6.92) observed in panicle initiation and the least amount of it (2.67) observed in panicle emergence. Considering effectiveness of salinity on unfilled panicles, different growth stages showed different sensitivity to salinity; panicle initiation was the most sensitive stage to salinity and after that were tillering, ripening and panicle emergence stages. In general, primary growth stages showed more sensitivity to salinity than final growth stages.

In survey of reciprocal effect of different levels of salinity and different growth stages (Fig. 3), it was observed that the most number of unfilled panicles (10.00) was in panicle initiation at $4 \mathrm{dSm}^{-1}$ and the least amount was 0.8 in control treatment.

Percentage of ratio of number of unfilled panicles to tillers

Conclusions of variance analysis (Table 1) showed that the effect of different growth stages on percentage of ratio of number of unfilled panicles to tillers was significant but effect of different levels of salinity was not significant $(P<0.05)$. High effectiveness of salinity on rice and sensitivity of rice to salinity of irrigation water has been reported by many researchers (Beatriz et al., 2001; Zeng et al., 2003). Salinity of water or soil decreases numbers of panicle and increases numbers of tillers (Beatriz et al., 2001). Razzaque et al., (2009) showed that salinity above $3 \mathrm{dSm}^{-1}$ sharply reduced all growth characters.
Research article

(CIndian Society for Education and Environment (iSee)
"Salinity stress"

http://www.indjst.org
F.Aref \& H.E.Rad Indian J.Sci.Technol. 
Fig. 1. Effect of salinity levels at different growing stages on the total number of empty grains per panicles

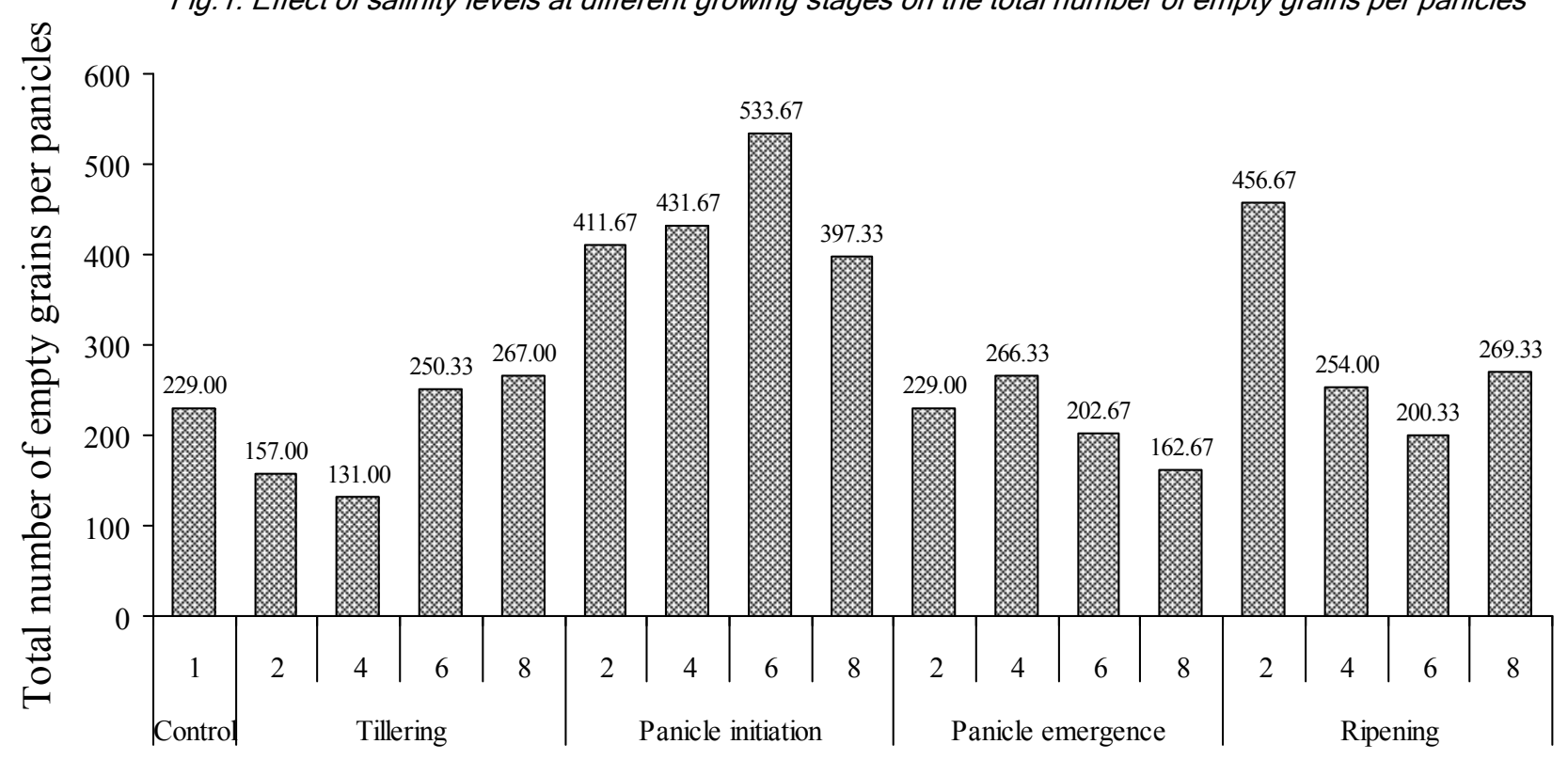

Different salinity levels $(\mathrm{dS} / \mathrm{m})$ at different growth stages

Fig. 2. Effect of salinity levels at different growing stages on the percentage of filled grains per panicle

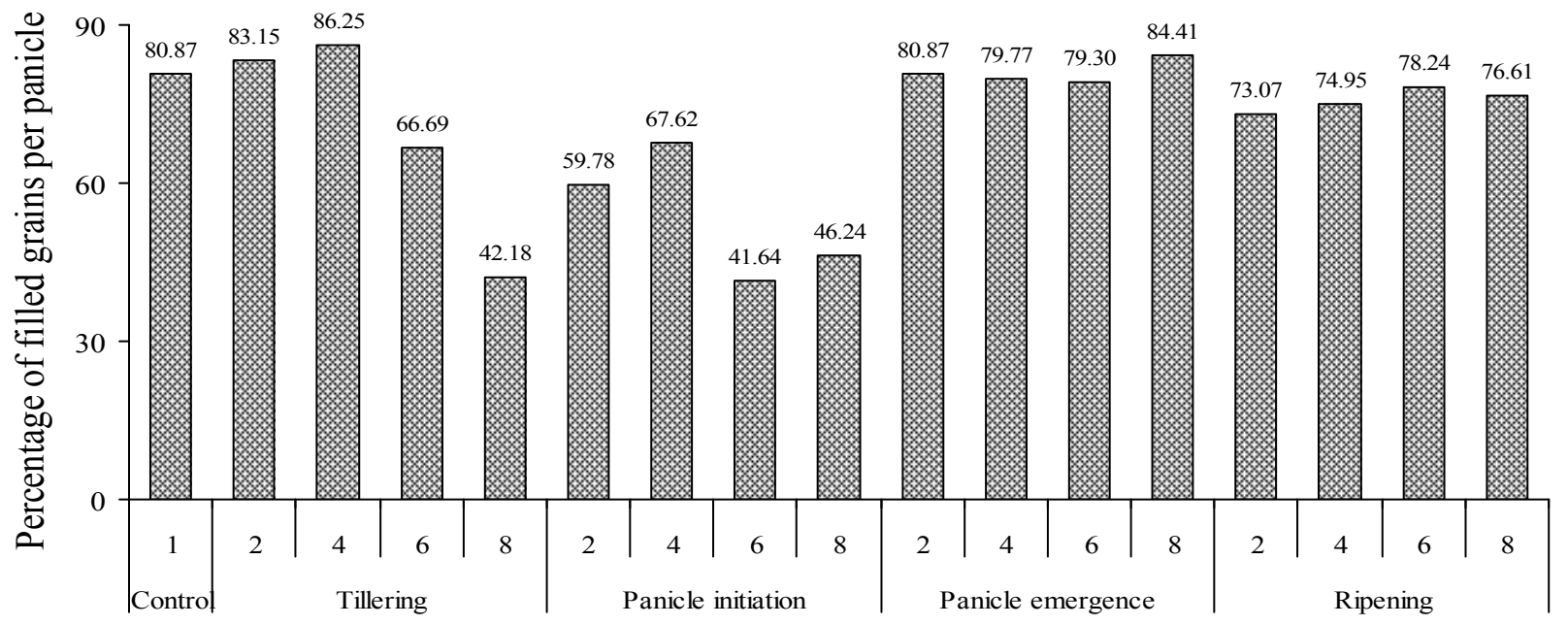

Different salinity levels $(\mathrm{dS} / \mathrm{m})$ at different growth stages

With regard to the conclusions of mean comparison of percentage of ratio of number of unfilled panicles to tillers (Table 2$)$, control treatment $\left(1 \mathrm{dSm}^{-1}\right)$ had the least percentage of ratio of number of unfilled panicles to tillers (5.40). Increased salinity increased percentage of ratio of number of unfilled panicles to tillers so that it increased from 2 to $8 \mathrm{dSm}^{-1}$ and the most amount of it (19.95) observed at $8 \mathrm{dSm}^{-1}$. Percentage of ratio of number of unfilled panicles to tillers is one of the determining factors of yield so that whatever this ratio increases, yield decreases too.

In different growth stages of rice, percentage of ratio of number of unfilled panicles to tillers was different. The most percentage of ratios of number of unfilled panicles to tillers (26.53) observed in panicle initiation and the least of it (10.58) observed in panicle emergence. Panicle initiation was the most sensitive stage to salinity and after that were tillering, ripening and panicle emergence stages.

Survey in reciprocal effect of different levels of salinity in growth stages (Fig. 4) showed that the most percentage of ratios of number of unfilled panicles to tillers (37.26) observed in panicle initiation at $4 \mathrm{dS} \mathrm{m}^{-1}$ and the least amount of it (4.55) observed in tillering at 4 dS $\mathrm{m}^{1}$. 


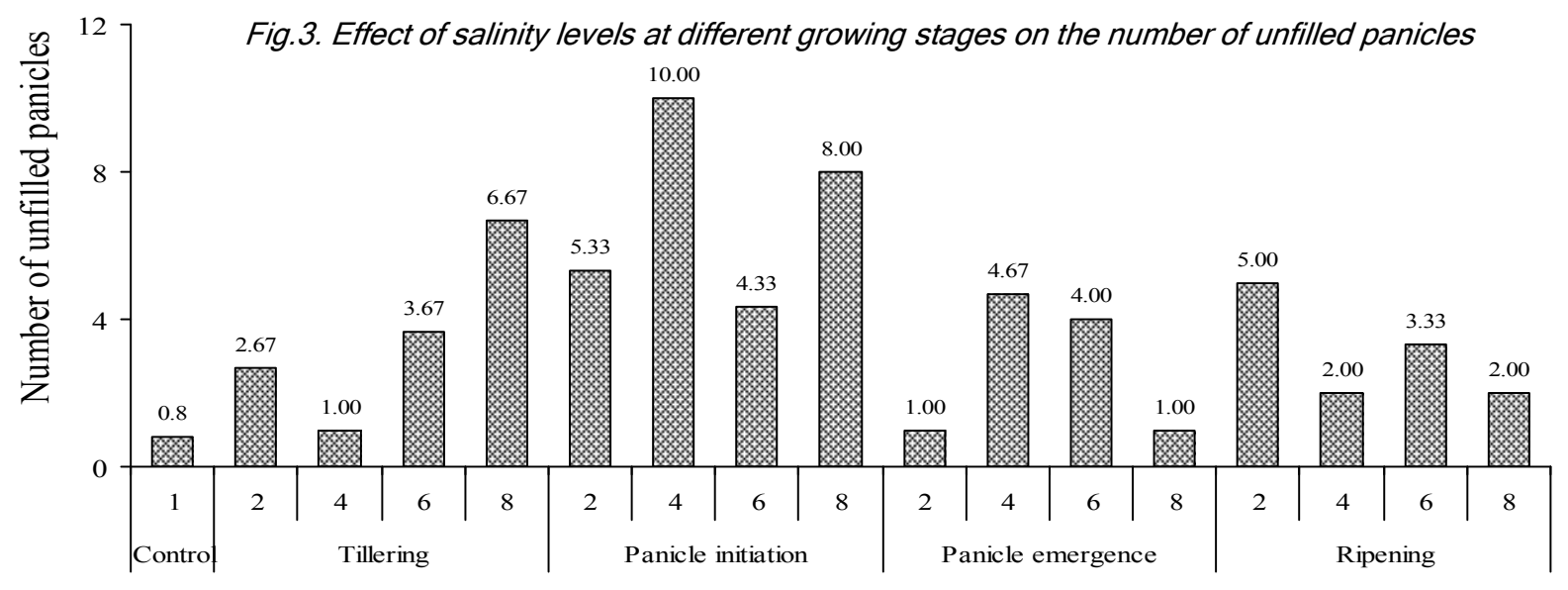

Different salinity levels $(\mathrm{dS} / \mathrm{m})$ at different growth stages

Fig.4. Effect of salinity levels at different growing stages on the percentage of ratio of number of unfilled

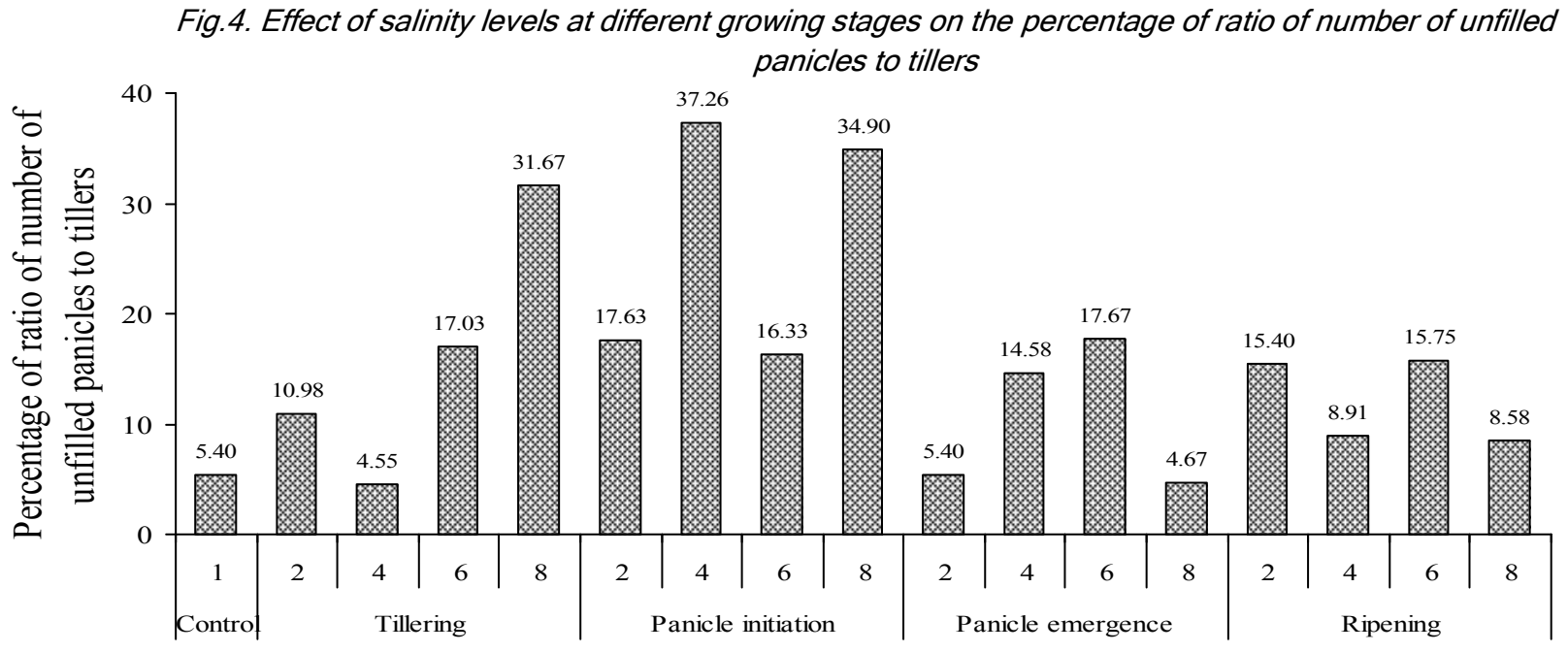

Different salininity levels $(\mathrm{dS} / \mathrm{m})$ at different growth stages

\section{References}

1. Abdullah Z, Khan MA and Flowers TJ (2001) Causes of sterility in seed set in rice under salinity stress. J. Agron. Crop Sci. 187, 25-32.

2. Asch F and Wopereis MCS (2001) Responses of fieldgrown irrigated rice cultivars to varying levels of floodwater salinity in a semi-arid environment. Field Crop Res. 70, 127-137.

3. Ashraf M and Harris PJC (2004) Potential biochemical indicators of salinity tolerance in plants. Plant Sci. 166, 3-16.

4. Ashraf M and O'Leary JW (1995) Distribution of cations in leaves of salt-tolerant and saltsensitive lines of sunflower under saline conditions. J. Plant Nutr. 18, 2379-2388.

5. Beatriz G, Piestun N and Bernstein N (2001) Salinityinduced inhibition of leaf elongation in maize Is not mediated by changes in cell wall. Plant Physiol. 125, 1419-1428.

6. Borsani O, Valpuesta V and Botella MA (2001) Evidence for a role of salicylic acid in the oxidative damage generated by $\mathrm{NaCl}$ and osmotic stress in Arabidopsis seedlings. Plant Physiol. 126, 1024-1030.

7. Caines AM and Shennan C (1999) Interactive effects of $\mathrm{Ca}^{2+}$ and $\mathrm{NaCl}$ salinity on the growth of two tomato genotypes differing in $\mathrm{Ca}^{2+}$ use effkiency. Plant Physiol. Biochem. 37(7,8), 569-576.

8. Castillo EG, Tuong TP, Ismail AM and Inubushi $\mathrm{K}$ (2007) Response to salinity in rice: Comparative effects of osmotic and ionic stresses. Plant Prod. Sci. $10,159-170$

9. Cha-um S and Kirdmanee C (2010) Effect of glycinebetaine on proline, water use and photosynthetic efficiencies and growth of rice seedlings under salt stress. Turk. J. Agric. For. 34, 517-527.

10.Cui H, Takeoka Y and Wada T (1995) Effect of sodium chloride on the panicle and spikelet morphogenesis in rice. Jpn. J. Crop Sci. 64, 593-600.

11.Darwish E, Testerink C, Khalil M, El-Shihy $O$ and Munnik T (2009) Phospholipid signaling responses in
Research article

CIndian Society for Education and Environment (iSee)
F.Aref \& H.E.Rad Indian J.Sci.Technol. 
salt-stressed rice leaves. Plant Cell Physiol. 50(5), 986-997.

12.Dhanapackiam S, and Muhammad Ilyas MH (2010a) Effect of salinity on chlorophyll and carbohydrate contents of sesbania grandiflora seedlings. Indian J. Sci. Technol. 3(1), 64-66.

13. Dhanapackiam S, and Muhammad llyas MH (2010b) Leaf area and ion contents of Sesbania grandiflora under $\mathrm{NaCl}$ and $\mathrm{Na}_{2} \mathrm{SO}_{4}$ salinity. Indian J. Sci. Technol. 5(3), 561-563.

14.El-Mouhamady AA, El-Demardash IS and Aboud KA (2010) Biochemical and molecular genetic studies on rice tolerance to salinity. J. Am. Sci. 6(11), 521-535.

15.El-Saidi MT (1997) Salinity and its effect on growth, yield and some physiological processes of crop plants. In: Jaiwal PK, Singh RP and Gulati A, editors. Strategies for Improving Salt Tolerance in Higher Plants. Enfield, NH, USA: Science Pub.

16. Eraslan F, Inal A, Gunes A and Alpaslan M (2007) Impact of exogenous salicylic acid on the growth, antioxidant activity and physiology of carrot plants subjected to combined salinity and boron toxicity. Sci. Hort. 113, 120-128.

17.Eynard A, Lal R and Wiebe $K$ (2005) Crop response in salt-affected soils. J. Sustain. Agric. 27(1), 5-50.

18.Fabre D, Siband P and Dingkuhn M (2005) Characterizing stress effects on rice grain development and filling using grain weight and size distribution. Field Crop Res. 92, 11-16.

19.Flowers TJ and Flowers SA (2005) Why does salinity pose such a difficult problem for plant breeders? Agr. Water Manage. 78, 15-24.

20.Fraga TI, Carmona FC, Anghinoni I, Junior SAG and Marcolin E (2010) Flooded rice yield as affected by levels of water salinity in different stages of its cycle. R. Bras. Ci. Solo. 34, 175-182.

21.Ghassemi F, Jakeman AJ and Nix HA (1995) Global resource overview. In: Ghassemi $F$, Jakeman $A J$ and Nix HA, editors. Salinization of Land and Water Resources. Wallingford,Oxon UK: CAB International. p 2-19.

22.Gunes A, Inal A, Alpaslan M, Eraslan F, Bagci EG and Cicek N (2007) Salicylic acid induced changes on some physiological parameters symptomatic for oxidative stress and mineral nutrition in maize ( $Z e a$ mays L.) grown under salinity. J. Plant Physiol. 164, 728-736.

23. Haq T, Akhtar J, Nawaz S and Ahmad R (2009) Morpho-physiological response of rice (Oryza sativa L.) varieties to salinity stress. Pak. J. Bot. 41(6), 29432956.

24. Hasegawa PM, Bressan RA, Zhu JK and Bohnert HJ (2000) Plant cellular and molecular responses to high salinity. Ann. Rev. Plant Physiol. Mol. Biol. 51, 463499.

25. Hopkins WG (1999) Introduction to Plant Physiology. John Wiley \& Sons, Inc., NY, USA.
26. Hoshida H, Tanaka Y, Hibino T, Hayashi Y, Tanaka A and Takabe $T$ (2000) Enhanced tolerance to salt stress in transgenic rice that overexpresses chloroplast glutamine synthetase. Plant Mol. 43, 103111.

27. Huang C, He W, Guo J, Chang X, Su P and Zhang L (2005) Increased sensitivity to salt stress in an ascorbate-deficient Arabidopsis mutant. J. Exp. Bot. 56, 3041-3049.

28. Jampeetong $A$ and Brix $\mathrm{H}$ (2009) Effects of $\mathrm{NaCl}$ salinity on growth, morphology, photosynthesis and proline accumulation of Salvinia natans. Aquat. Bot. 91, 181-186.

29. Khan MSA, Hamid A and Karim MA (1997) Effect of sodium chloride on germination and seedling characters of different types of rice (Oryza sativa L.) J. Agron. Crop Sci. 179, 163-169.

30. Khatun S and Flowers TJ (1995) Effects of salinity on seed set in rice. Plant Cell Environ. 18, 61-67.

31. Khatun S, Rizzo CA and Flowers TJ (1995) Genotypic variation in the effect of salinity on fertility in rice. Plant Soil 173, 239-250.

32. Koyro HW (2006) Effect of salinity on growth, photosynthesis, water relations and solute composition of the potential cash crop halophyte Plantago coronopus (L.). Environ. Exp. Bot. 56, 136146.

33.Lambers H, Stuart Chapin F and Pons TL (1998) Plant physiological ecology. Springer-Verlaz. NY, USA.

34.Lauchli A and Epstein E (1990) Plant responses to saline and sodic conditions. In: Agricultural salinity assessment and management. ASCE Manuals and Reports No 71. Tanji KK (ed.) ASCE, NY, USA. pp: 1130-1137.

35.Lauchli A and Grattan SR (2007) Plant growth and development under salinity stress. In: Advances in molecular breeding toward drought and salt tolerant crops. Jenks MA, Hasegawa PM \& Jain SM (eds.) Springer, Dordrecht, The Netherlands. pp:1-32.

36. Maas EV and Hoffman GJ (1997) Crop salt tolerancecurrent assessment. J. Irrig. Drain. Div. Am. Soc. Civ. Eng. 103, 115-134.

37. Maathuis FJM and Amtmann A (1999) $\mathrm{K}^{+}$nutrition and $\mathrm{Na}^{+}$toxicity: the basis of cellular K/Na ratios. Ann. Bot. 84, 123-133.

38. Marschner M (1995) Mineral nutrition of higher plants. Academic Press, London.

39. Mohammadi Nejada G, Singhb RK, Arzanic A, Rezaiec AM, Sabourid H and Gregoriob GB (2010) Evaluation of salinity tolerance in rice genotypes. Int J. Plant Prod. 4(3), 199-207.

40.Momayezi MR, Zaharah AR, Hanafi MM and Mohd Razi I (2009) Agronomic characteristics and proline accumulation of Iranian rice genotypes at early seedling stage under sodium salts stress. Malays. J. Soil Sci. 13, 59-75.
Research article

Clndian Society for Education and Environment (iSee)
"Salinity stress"

http://www.indjst.org
F.Aref \& H.E.Rad Indian J.Sci.Technol. 
41. Moradi F and Ismail AM (2007) Responses of photosynthesis, chlorophyll fluorescence and ROSscavenging systems to salt stress during seedling and reproductive stages in rice. Ann. Bot. 99, 1161-1173.

42. Muhling KH and Lauchli A (2002) Effect of salt stress on growth and cation compartmentation in leaves of two plant species differing in salt tolerance. J. Plant Physiol .159, 137-146.

43. Munns R (1993) Physiological processes limiting plantgrowth in saline soils - some dogmas and hypotheses. Plant Cell Environ. 16, 15-24.

44. Munns R (2002) Comparative physiology of salt and water stress. Plant Cell Environ. 25, 239-250.

45. Murchie EH, Yang J, Hubbart S, Horton P and Peng S (2002) Are there associations between grain-filling rate and photosynthesis in the flag leaves of field-grown rice? J. Exp. Bot. 53, 2217-2224.

46. Nishimura T, Cha-um S, Takagaki M and Ohyama K (2011) Survival percentage, photosynthetic abilities and growth characters of two indica rice (Oryza sativa L. spp. indica) cultivars in response to iso-osmotic stress. Span. J. Agric. Res. 9(1), 262-270.

47. Pagter $M$, Bragato $C$, Malagori $M$ and Brix $H$ (2009) Osmotic and ionic effects of $\mathrm{NaCl}$ and $\mathrm{Na}_{2} \mathrm{SO}_{4}$ salinity on Phragmites australis. Aquat. Bot. 90, 43-51.

48. Parida $A K$ and Das AB (2005) Salt tolerance and salinity effects on plants: a review. Ecotoxicol. Environ. Safe. 60, 324-349.

49. Quintero JM, Fournier JM, Benlloch M and RodriguezNavarro A (2008) $\mathrm{Na}^{+}$accumulation in root symplast of sunflower plants exposed to moderate salinity is transpiration-dependent. J. Plant Physiol. 165, 12481254.

50. Razzaque MA, Talukder NM, Islam MS, Bhadra AK and Duta RK (2009) The effect of salinity on morphological characteristics of seven Rice (Oryza sativa) genotypes differing in salt tolerance. Pak. J. Biol. Sci. 12(5), 406412.

51. SAS (2001) SAS user's guide of release version 8.2. Cary, NC: SAS Inst.

52. Sepaskhah AR and Yousofi-Falakdehi A (2010) Rice yield modeling under salinity and water stress conditions using an appropriate macroscopic root water uptake equation. Pak. J. Biol. Sci. 13, 1099-1105.

53. Sheehy JE, Dionora MJA and Mitchell PL (2001) Spikelet numbers, sink size and potential yield in rice. Field Crop Res. 71, 77-85.

54. Shereen A, Mumtaz S, Raza S, Khan MA and Solangi S (2005) Salinity effects on seedling growth and yield components of different inbred rice line. Pak. J. Bot. 37(1), 131-139.

55. Silva EIL (2004) Quality of irrigation water in Sri Lankastatus and trends. J. Water Environ. Pollution, 1, 5-12.

56. Singh AK, Ansari MW, Pareek A and Singla-Pareek SL (2008) Raising salinity tolerant rice: recent progress and future perspectives. Physiol. Mol. Biol. Plant, 14, 137154.

57. Siringam K, Juntawong N, Cha-um S and Kirdmanee C (2011) Salt stress induced ion accumulation, ion homeostasis, membrane injury and sugar contents in salt-sensitive rice (Oryza sativa L. spp. indica) roots under isoosmotic conditions. Afr. J. Biotech. 10(8), 13401346.

58. Tanou G, Molassiotis A and Diamantidis G (2009) Induction of reactive oxygen species and necrotic deathlike destruction in strawberry leaves by salinity. Environ. Exp. Bot. 65, 270-281.

59. Tarakcioglu $C$ and Inal A (2002) Changes induced by salinity, demarcating specific ion ratio $(\mathrm{Na} / \mathrm{Cl})$ and osmolality on ion and proline accumulation, nitrate reductase activity and growth performance of lettuce. $J$. Plant Nutr. 25, 27-41.

60. Teixeira J and Pereira S (2007) High salinity and drought act on an organ-dependent manner on potato glutamine synthetase expression and accumulation. Environ. Exp. Bot. 60, 121-126.

61. Tester $\mathrm{M}$ and Davenport $\mathrm{R}(2003) \mathrm{Na}^{+}$tolerance and $\mathrm{Na}^{+}$ transport in higher plants. Ann. Bot. 91, 503-527.

62. Tsuda M (1993) Grain filling in rice subjected to drought at three stages. Jpn. J. Crop Sci. 62, 199-205.

63. Turkan I and Demiral T (2009) Recent developments in understanding salinity tolerance. Environ. Exp. Bot. 67, 29.

64. Tuteja N (2007) Mechanisms of high salinity tolerance in plants. Methods Enzymol. 428, 419-438.

65. Vaidynathan $H$, Sivakumar $P$, Chakrabarty $R$ and Thomas G (2003) Scavenging of reactive oxygen species in $\mathrm{NaCl}$-stressed rice (Oryza sativa L.) differential response in salt-tolerant and sensitive varieties. Plant Sci. $165,1411-1418$.

66. Verma S and Mishra SN (2005) Putrescine alleviation of growth in salt stressed Brassica juncea by inducing antioxidative defense system. J. Plant Physiol. 162, 669677.

67. Winicov I (1993) Enhanced gene expression in salt tolerance of alfalfa cell lines and regenerated plants. In: Enhanced gene expression in salt tolerance of alfalfa cell lines and regenerated plants. Verma DPS (ed.), CRC Press, NY, pp: 301-310.

68. Winicov I (1998) New molecular approaches to improving salt tolerance in crop plants. Ann. Bot. 82, 703-710.

69. Yang-Ren W, Shao-Zhong K, Fu-Sheng L, Lu Z and JianHua Z (2007) Saline water irrigation scheduling through a crop-water-salinity production function and a soil-watersalinity dynamic model. Pedosphere, 17(3), 303-317.

70. Zaibunnisa A, Khan MA, Flowers TJ, Ahmad R and Malik KA (2002) Causes of sterility in rice under salinity stress. In: Prospects for saline agriculture. Ahmad R (Ed.), Kluwer, The Netherlands. pp:177-187.

71.Zeng L, Lesch SM and Grieve CM (2003) Rice growth and yield respond to changes in water depth and salinity stress. Agr. Water Manage. 59, 67-75.

72. Zeng $L$ and Shannon MC (2000) Salinity effects on seedling growth and yield components of rice. Crop Sci. 40, 996-1003.

73.Zeng L, Shannon MC and Lesch SM (2001) Timing of salinity stress effects rice growth and yield components. Agr. Water Manage. 48, 191-206. 